\title{
Fungus and Actinomycetes Diversity of Exophytic and Endophytic in Red Grape and its Inhibition Ability to Pathogen Aspergillus niger (Caused Rot Fruit Grape)
}

\author{
I. Made Sudarma*, Ni Nengah Darmiati and Ni Wayan Suniti \\ Department of Agroecotechnology Study Program, College of Agriculture, Udayana \\ University. Jl. PB. Sudirman Denpasar, India \\ *Corresponding author
}

\begin{tabular}{|l|}
\hline K e y w o r d s \\
Exophytes, \\
Endophytes, Red \\
grapes, A. niger and \\
Neurospora sp \\
\hline Article Info \\
\hline $\begin{array}{l}\text { Accepted: } \\
\text { 17 September } 2019 \\
\text { Available Online: } \\
\text { 10 October } 2019\end{array}$ \\
\hline
\end{tabular}

A B S T R A C T
Red grape rotten in storage is a major problem for consumers, moreover the fruit after offering in Pura (Bali island) cannot be stored for long. Efforts to control environmentally friendly diseases are hopeful in the future, using exophytic and endophytic fungi derived from healthy red grapes that need to be utilized. The results showed that red grape rot was caused by Aspergillus niger. Fungi/actinomycetes found in exophytes were 19 isolates while those of endophytes consisted of 5 isolates. Microbes found that have the highest inhibitory power by the fungus Neurospora sp. by $88.89 \%$, and followed by Streptomyces antagonensis and A. flavus respectively at $83.33 \%$. Colonies and the highest prevalence were found in A. flavus at $282.72 \mathrm{cfu} / \mathrm{ml}$ of water. Diversity index and index dominance of fungal/actinomycetes of 2.088 and 0.8209 means that the index of diversity is moderate and the index of dominance is high close to one reached by A. flavus. The results of the best antagonist inhibitory test (Neurospora sp.) in vivo showed that the concentration of suspension solution of $250 \mathrm{ml}$ antagonist water spores $(10-7 / \mathrm{ml}$ water $)$ was the best compared to other treatments.

\section{Introduction}

Aspergillus niger is one of the most species of fungi from the genus Aspergillus. Fungi that cause black mold on a variety of fruits and vegetables such as grapes, shallots, peanuts are generally foods that are easily contaminated. This fungus is everywhere which contaminates the environment in the room. Aspergillus niger is generally asexual even though it has a perfect shape (reproducing sexually). Geographically this fungus is widespread with a range of habitats because it can colonize various substrates. 
Generally this fungus is found as saprophitis which grows on the leaves of dead plants, stored seeds, compost and decayed vegetation. Scattered spores are often associated with organic matter and soil (Sharma, 2012).

In an effort to control red grape rot, control is sought by utilizing exophytic and endophytic fungi from healthy fruit. Endophytes are microorganisms that live within the intercellular surface of the stem, petiole, roots, leaves and fruit of the plant and their existence cannot be seen and does not cause disease to the host (Caroll, 1998; Strobel and Long, 1998; Yang et al., 2011). Most endophytic fungi produce secondary metabolites such as auxin, giberallin, etc. which help in the growth and development of host plants. Some of these compounds are antibiotics that have antifungal properties, are antibacterial and have insecticidal properties, which strongly inhibit the growth of other microbes, including plant pathogens (Dutta et al., 2014). Conversely, fungi that live exophitic on the surface of plants can inhibit the growth of pathogens both antibiotic and competitive. For example the results of a study by Yadav et al., (2011) tested philoplane fungi (Trichoderma viride and Aspergillus flavus) inhibiting petogen growth (Alternaria brassicae). The antagonistic effect of saprophytic microbes has been reported by many researchers (Goswami and Islam, 2002; Perello et al., 2006).

The aim of the study was to determine the diversity of endophytic fungi and their ability to suppress the growth of pathogens (A. niger) both in vitro and in vivo.

\section{Materials and Methods}

\section{Place and time of research}

The study was conducted in two places: 1) looking for sick, healthy plant specimens from grapes on the market 2) Laboratory of Plant Diseases and Biotechnology Laboratory of the Faculty of Agriculture, Udayana University. The research was conducted from April to August 2019.

\section{Endophyticand exophytic fungus isolation}

Endophytic isolation, part of the fruit plant, is washed with sterile running water, then the part of the plant is strained with $0.525 \%$ sodium hypochlorite for 3 minutes, and $70 \%$ alcohol for 2 minutes, then rinsed with sterile water for 1 minute and then placed on PDA media (which were first given anti-bacterial antibiotics namely livoploxasin with a concentration of $0.1 \%(\mathrm{w} / \mathrm{v})$.

Fungi that emerge from leaf pieces are transferred to test tubes containing PDAs to be stored and classified through morphospecies.

While exophytic fungi can be done by spraying fruit parts. The washing water is collected, then in a tube, then diambi, from a 1 $\mathrm{ml}$ tube it grows into a PDA which was previously filled with livoploxasin with a concentration of $0.1 \%(\mathrm{w} / \mathrm{v})$.

\section{Identification of Endophytic and Exophytic Fungi and Actinomycetes}

Endophyticand exophytes fungi and actinomycetes stored next were grown in Petri dishes containing PDAs and repeated 5 times. The culture incubated in the dark room at room temperature $\left( \pm 27^{\circ} \mathrm{C}\right)$.

Isolates were identified macroscopically after 3 days of age to determine colony color and growth rate, and identify microscopically to determine septa in hyphae, spore/conidia and sporangiophore forms.

Fungal identification using the reference book Samson et al., 1981; Pitt and Hocking, 1997; 
Barnett and Hunter, 1998; and Indrawati et al., 1999 and Ghai et al., 2012).

\section{Antagonistic inhibitory test against pathogens}

Endophytic fungi and exophytes and actinomycetes which were found each were tested for their inhibitory power on the growth of pathogenic fungi with dual culture techniques (in one Petri dish grown each one pathogenic fungus flanked with two antagonistic). Its inhibitory power can be calculated as follows (Mojica-Marin et al., 2008):

Inhibition ability $(\%)=\mathrm{A}-\mathrm{B} / \mathrm{A} \times 100$

Where: $\mathrm{A}=$ Diameter of $A$. niger colonies in single culture (mm)

$\mathrm{B}=$ Diameter of $A$. niger colonies in dual culture $(\mathrm{mm})$

Endophytic and exophytic fungi and actinomycetes prevalence

Determining the prevalence of endophytic and exophytes fungi and actinomycetes was based on the frequency of endophytic and exophytes fungi and actinomyecetes found fruit per Petri dish, divided by all isolates found $100 \%$ times.

The large prevalence of isolates will determine the dominance of endophytic fungi in the healthy grape portion.

\section{Determining the diversity and domination} index

The diversity and dominance of fungal contaminants can be known by calculating the Shannon-Wiener diversity index (Odum, 1971) and microbial dominance calculated by calculating the Simpson index (Pirzan and Pong-Masak, 2008).

\section{Index of microbial diversity}

The index of microbial diversity is determined by the Shannon-Wiener diversity index, namely the formula (Odum, 1971):

$$
\mathrm{H}_{\mathrm{i}=1}^{\mathrm{s}}=-\sum P i \ln P i .
$$

Where:

$\mathrm{H}^{\prime}=$ the Shannon-Wiener diversity index

$S=$ Number of genus

$\mathrm{Pi}=\mathrm{ni} / \mathrm{N}$ as proportion to type $\mathrm{i}(\mathrm{ni}=$ Total number of individuals of total microbes $\mathrm{i}, \mathrm{N}=$ Total of all individuals in total $\mathrm{n}$ )

The criteria used to interpret the diversity of Shannon-Wiener (Ferianita-Fachrul et al., 2005) are: H'value <1, means diversity is low, $\mathrm{H}^{\prime}$ value 1 - 3 means that diversity is moderate and $\mathrm{H}^{\prime}$ value> 3 means diversity is classified high.

\section{Index of dominance}

The dominance index of soil microbes is calculated by calculating the Simpson index (Pirzan and Pong-Masak, 2008), with the following formula:

$$
\underset{\mathrm{i}=1}{\mathrm{C}=\sum P i^{2}}
$$

Where:

$\mathrm{C}=$ Simpson index

$\mathrm{S}=$ Number of genus

$\mathrm{Pi}=\mathrm{ni} / \mathrm{N}$ which is the proportion of individuals of type $\mathrm{i}$ and all individuals ( $\mathrm{ni}=$ 
total number of individuals of type i, $\mathrm{N}=$ number of all individuals in total $\mathrm{n}$ ).

Furthermore the species dominance index (D) can be calculated with formulations $1-\mathrm{C}$ ( Rad et al., 2009). Criteria used to interpret the dominance of microbial species are: close to 0 = low index or the lower dominance by one microbial species or no species that dominates the other species to an extreme, close to $1=$ large index or tend to be dominated by several microbial species (Pirzan and Pong -Masak, 2008)

\section{Antagonistic test by in vivo}

In vivo antagonistic tests of endophytic and exophytic microbes that have the best inhibitory power are used by dipping into the suspension of antagonistic fungal spores (each according to treatment), then dipped into the suspension of pathogenic fungal spores. The best treatments for endophytic and exophytic microbes are:

$\mathrm{A}=$ control (without being smeared with antagonists) + pathogens

$\mathrm{B}=$ antagonist treatment $(250 \mathrm{ml}$ aqua $(10 \%$ sugar mixture) + spore suspension 1 Petri dish) + pathogen

$\mathrm{C}=$ antagonist treatment $(500 \mathrm{ml}$ aqua $(10 \%$ sugar solution) + spore suspension 1 Petri dish) + pathogen

$\mathrm{D}=$ antagonistic treatment $(750 \mathrm{ml}$ aqua $(10 \%$ sugar solution) + spore suspension 1 Petri dish) + pathogen

$\mathrm{E}=$ antagonist treatment $(1000 \mathrm{ml}$ aqua $(10 \%$ sugar solution) + spore suspension 1 Petri dish) + pathogen

$\mathrm{F}=$ antagonist treatment $(1250 \mathrm{ml}$ aqua $(10 \%$ sugar solution) + spore suspension 1 Petri dish)
$\mathrm{G}=$ without any treatment

All treatments were repeated 5 times. The experiment was designed with a completely randomized design (CRD), and after analysis of variance (ANOVA) continued with the smallest real difference test (LSD) at the level of $5 \%$. The attack parameters measured by the formulation: the fruit is divided by all the fruits observed $100 \%$.

\section{Results and Discussion}

\section{Pathogen identification}

Based on the results of isolation on red grape rotten fruit it was found that the pathogen causing rotten fruit is Aspergillus niger. This result is strengthened by three times the isolation still obtained by $A$. niger as a pathogen (Figure 1).

\section{Type of endophytic and exophytic microbes and inhibition ability on pathogen}

Based on the results of the study, 19 fungal/Actinomycetes exophytic isolates and 5 endophytic fungal isolates in red wine were obtained (Table 1). Isolates which have a inhibitory power of 19 fungi/Actinomycetes exophytes are only 3 which show inhibition, each Neurospora sp. (Exo 3) of 88.89\%, Neurosporasp. (Exo 5) of $77.78 \%$ and Streptomyces otagonensis (Esko 18) of $83.33 \%$. Whereas in endophytes, only 3 isolates were found to have a inhibitory capacity of A. flavus (Endo 1, Endo 3 and Endo 4) with inhibition of $83.33 \%$ (Table 1). Means found with the best inhibitory power is in the exophytic fungus Neurospora sp.

Fungal/Actinomycetes colonies found in red wine from $35.34 \mathrm{cfu} / \mathrm{ml}$ water to 282.72 $\mathrm{cfu} / \mathrm{ml}$ water. The colony is largely dominated by A. falvus, followed by Ornithinimicrobium humiphilum (Actinomycetes) and Neurospora 
sp., Pseudonocordia spinose and Streptomyces otagonensis (Table 1; Figure 2).

\section{Diversity and dominance index of fungal/actinomycetes on red grape}

Based on observations and analysis results it was found that the index of diversity of fungi/Actinomycetes in red wine was 2.08821, while the dominance index was 0.8209 . The diversity index 2.08821 is below the maximum diversity index (6.66375), so there is a dominance in the habitat. Evidenced by the dominance index approaching the number 1 (one) that is equal to 0.8209 . The colony of A.flavus dominates at $282.72 \mathrm{cfu} / \mathrm{ml}$ of water (Table 2).

Best antagonistic test results with pathogens in red wine in vivo

The results of statistical analysis showed that all treatments with the best isolate (Naurospora sp.) Had a very significant effect on control (treatment with pathogens) except treatment $\mathrm{E}$ and $\mathrm{F}$ which were not real with control on red wine. The mean in treatment $\mathrm{B}$ obtained attack intensity $65 \pm 4.47 \%$, as well as treatment $\mathrm{C}$ was $78 \pm 5.10 \%$ (Table 3; Figure 3).

Aspergillus niger is a pathogen in black onion rot (Khokhar et al., 2012). This widespread fungus which is a member of ascomycotina, has been isolated from a number of habitats. A. niger is a fungus known as GRAS (generally recognized as safe) from US Food and Drug Administration. The dark black color shows mushrooms that have important products in the fermentation industry. But this fungus is spread throughout the world, carried by humans often through the spores and vegetative forms of $A$. niger in the air, in food and other storage products and ties the problem of suffering with allergies. A. niger can also produce certain mycotoxins which are heptocarcinogenic, nephrogenic immunological. Furthermore this fungus is a causative agent for several plant rot diseases (Gautam et al., 2011).

Aspergillus niger is commonly found growing saprophitis on dead leaves, stored seeds, compost mounds and other decayed vegetation.

Microscopically the conidiophore is smoothwalled, hyaline or black-colored towards the vesicle. The head is a conidia is biseriate with growing brown colored philiade, often with matulae. Conidia are round to slightly round with a diameter of $3.5-5.0 \mu \mathrm{m}$, dark brown to black and rough-walled. It is known to be creative in increasing a number of pathogenicity in various plant species, which can be treated with antibiotics, chemicals and antibiosis (Sharma, 2012).

Neurospora sp. one of them is oncom (Neurospora sitophila) which is cultivated and useful for fermenting animal feed. This fungus produces intracellular carotinoid pigments that are stored in the conion, creating an orange appearance. Carotin is extracted from spores using acetone-hexana (2: 1) (Pahlevi et al., 2008). One effort to improve the quality of animal feed ingredients is fermentation using neurosporic carotenogenic molds.

This mold easily grows on aerobic fermented substrates in a short time. Fermentation with mold can reduce crude fiber, and increase crude protein and carotene substrate (Nurfaizin and Matitaputty, 2015).

The fungus and actinomycetes found in red wine are 11 types of fungus/actinomycetes, which consists of 3 types of fungus and 8 types of actinomyecetes. The highest colony was found in $A$. flavus with the number of colonies in red wine of $282.72 \mathrm{cfu} / \mathrm{ml}$ of water. The diversity index and the dominance 
index in the red wine diversity index reached 0.8209 . The highest prevalence is held by $A$. 2.0888 while the dominance index reached flavus.

Table.1 Type of endophytic and exophytic microbes and inhibition ability in vitro on red grape

\begin{tabular}{|c|c|c|c|c|c|}
\hline \multicolumn{3}{|c|}{ Exopjhytic microbes } & \multicolumn{3}{|c|}{ Endophytic microbes } \\
\hline Code & Name of microbes & $\begin{array}{l}\text { Inhibition } \\
\text { ability } \\
(\%)\end{array}$ & Code & $\begin{array}{l}\text { Name of } \\
\text { microbes }\end{array}$ & $\begin{array}{c}\text { Inhibition } \\
\text { ability } \\
(\%)\end{array}$ \\
\hline Exo 1 & $\begin{array}{l}\text { Turicella otitidis } \\
\text { (Actinomycetes) }\end{array}$ & - & Endo 1 & A. flavus & 83.33 \\
\hline Exo 2 & $\begin{array}{l}\text { Streptomycetes avermitilis } \\
\text { (Actinomycetes) }\end{array}$ & - & Endo 2 & $\begin{array}{l}\text { Aspergillus } \\
\text { sp. }\end{array}$ & - \\
\hline Exo 3 & Neurospora sp. & 88.89 & Endo 3 & A. flavus & 83.33 \\
\hline Exo 4 & Aspergillus flavus & - & Endo 4 & A. flavus & 83.33 \\
\hline Exo 5 & Neurospora sp. & 77.78 & Endo 5 & $\begin{array}{l}\text { Aspergillus } \\
\text { sp. }\end{array}$ & - \\
\hline Exo 6 & $\begin{array}{l}\text { Bogoriella caseilytica } \\
\text { (Actinomycetes) }\end{array}$ & - & & & \\
\hline Exo 7 & A. flavus & - & & & \\
\hline Exi 8 & S. otagonensis (Actinomycetes) & - & & & \\
\hline Exo 9 & $\begin{array}{c}\text { Pseudonocardiaspinose } \\
\text { (Actinomycetes) }\end{array}$ & - & & & \\
\hline Exo 10 & $\begin{array}{l}\text { Streptomycetes sp. } \\
\text { (Actinomycetes) }\end{array}$ & - & & & \\
\hline Exo 11 & $\begin{array}{l}\text { Ornithinimicrobium humiphilum } \\
\text { (Actinomycetes) }\end{array}$ & - & & & \\
\hline Exo 12 & $\begin{array}{l}\text { Ornithinimicrobium humiphilum } \\
\text { (Actinomycetes) }\end{array}$ & - & & & \\
\hline Exo 13 & $\begin{array}{l}\text { Streptomyces nobilis } \\
\text { (Actinomycetes) }\end{array}$ & - & & & \\
\hline Exo 14 & A. flavus & - & & & \\
\hline Exo 15 & A. flavus & - & & & \\
\hline Exo 16 & $\begin{array}{c}\text { Pseudonocardia spinose } \\
\text { (Actinomycetes) }\end{array}$ & - & & & \\
\hline Exo 17 & $\begin{array}{l}\text { Ornithinimicrobium humiphilum } \\
\text { (Actinomycetes) }\end{array}$ & - & & & \\
\hline Exо 18 & $\begin{array}{l}\text { Streptomyces otagonensis } \\
\text { (Actinomycetes) }\end{array}$ & 83.33 & & & \\
\hline Exo 19 & A. flavus & - & & & \\
\hline
\end{tabular}


Table.2 Analysis of diversity and dominance index in red grape

\begin{tabular}{|c|c|c|c|c|c|}
\hline Name offungi/Actinomycetes & $\begin{array}{c}\text { Colonies } \\
\text { (cfu)ml } \\
\text { air }\end{array}$ & pi/P & $\begin{array}{c}\mathbf{L N} \\
(\mathbf{p i} / \mathbf{P})\end{array}$ & $\begin{array}{c}\mathbf{p i} / \mathbf{P} \times \mathbf{L N} \\
(\mathbf{p i} / \mathbf{P})\end{array}$ & $(\mathbf{p i} / \mathbf{P}) 2$ \\
\hline Aspergillus flavus & 282.73 & 0.36085 & -1.01929 & -0.367812 & 0.1302139 \\
\hline Aspergillus sp. & 6 & 0.00765 & -4.87199 & -0.037310 & 5.86471 \\
\hline $\begin{array}{l}\text { Bogoriella caseilytica } \\
\text { (Actinomycetes) }\end{array}$ & 35.34 & 0.04510 & -3.09873 & -0.139773 & 0.002035 \\
\hline Neurospora $\mathbf{s p .}$ & 70.68 & 0.09021 & -2.40558 & -0.217015 & 0.008138 \\
\hline $\begin{array}{c}\text { Ornithinimicrobium humiphilum } \\
\text { (Actinomycetes) }\end{array}$ & 106.02 & 0.13531 & -2.00012 & -0.270655 & 0.018311 \\
\hline $\begin{array}{c}\text { Pseudonocardia spinose } \\
\text { (Actinomycetes) }\end{array}$ & 35.34 & 0.04510 & -3.09873 & -0.139773 & 0.002035 \\
\hline $\begin{array}{c}\text { Pseudonocardia spinose } \\
\text { (Actinomycetes) }\end{array}$ & 35.34 & 0.04510 & -3.09873 & -0.139773 & 0.002035 \\
\hline S. otagonensis (Actinomycetes) & 70.68 & 0.09021 & -2.40558 & -0.217015 & 0.008138 \\
\hline $\begin{array}{l}\text { Streptomyces nobilis } \\
\text { (Actinomycetes) }\end{array}$ & 35.34 & 0.04510 & -3.09873 & -0.139773 & 0.002035 \\
\hline $\begin{array}{l}\text { Streptomycetesavermitilis } \\
\text { (Actinomycetes) }\end{array}$ & 35.34 & 0.04510 & -3.09873 & -0.139773 & 0.002035 \\
\hline $\begin{array}{c}\text { Streptomycetes sp. } \\
\text { (Actinomycetes) }\end{array}$ & 35.34 & 0.04510 & -3.09873 & -0.139773 & 0.002035 \\
\hline $\begin{array}{l}\text { Turicella otitidis } \\
\text { (Actinomycetes) }\end{array}$ & 35.34 & 0.04510 & $-3,09873$ & $-0,139773$ & 0.002035 \\
\hline Jumlah & 783.48 & & & -2.08822 & 0.179103 \\
\hline
\end{tabular}

Ddominance index $=1-0.179103=0.8209, \mathrm{H}$ diversity index $=2.088822$

Table.3 Effect of best antagonistic treatment on fruit rot disease in red wine

\begin{tabular}{|c|c|c|c|}
\hline Treatment & Average of diseases incidance & \multicolumn{2}{|c|}{ Notation } \\
\cline { 3 - 4 } & $(\mathbf{\%})$ & $5 \%$ & $1 \%$ \\
\hline A & $100 \pm 00^{* *}$ & $\mathrm{a}$ & $\mathrm{a}$ \\
\hline B & $65 \pm 4.47$ & $\mathrm{c}$ & $\mathrm{b}$ \\
\hline C & $78 \pm 5.10$ & $\mathrm{~b}$ & $\mathrm{bc}$ \\
\hline D & $87 \pm 4.00$ & $\mathrm{~b}$ & $\mathrm{abc}$ \\
\hline E & $92 \pm 2.45$ & $\mathrm{a}$ & $\mathrm{ac}$ \\
\hline F & $95 \pm 4.47$ & $\mathrm{a}$ & $\mathrm{ac}$ \\
\hline G & $24 \pm 4.90$ & $\mathrm{~d}$ & $\mathrm{~d}$ \\
\hline
\end{tabular}

$\star \star$ The same letter in the same column means that it is not significantly different in the LSD test of 5\% and 1\% 
Fig.1 Pathogen identification. Rotten fruit (arrow) taken from the Batubulan market (A), (B) the isolation results are five pieces and repeated 3 times, and (C) microscopic pathogen observation (Aspergillus niger)
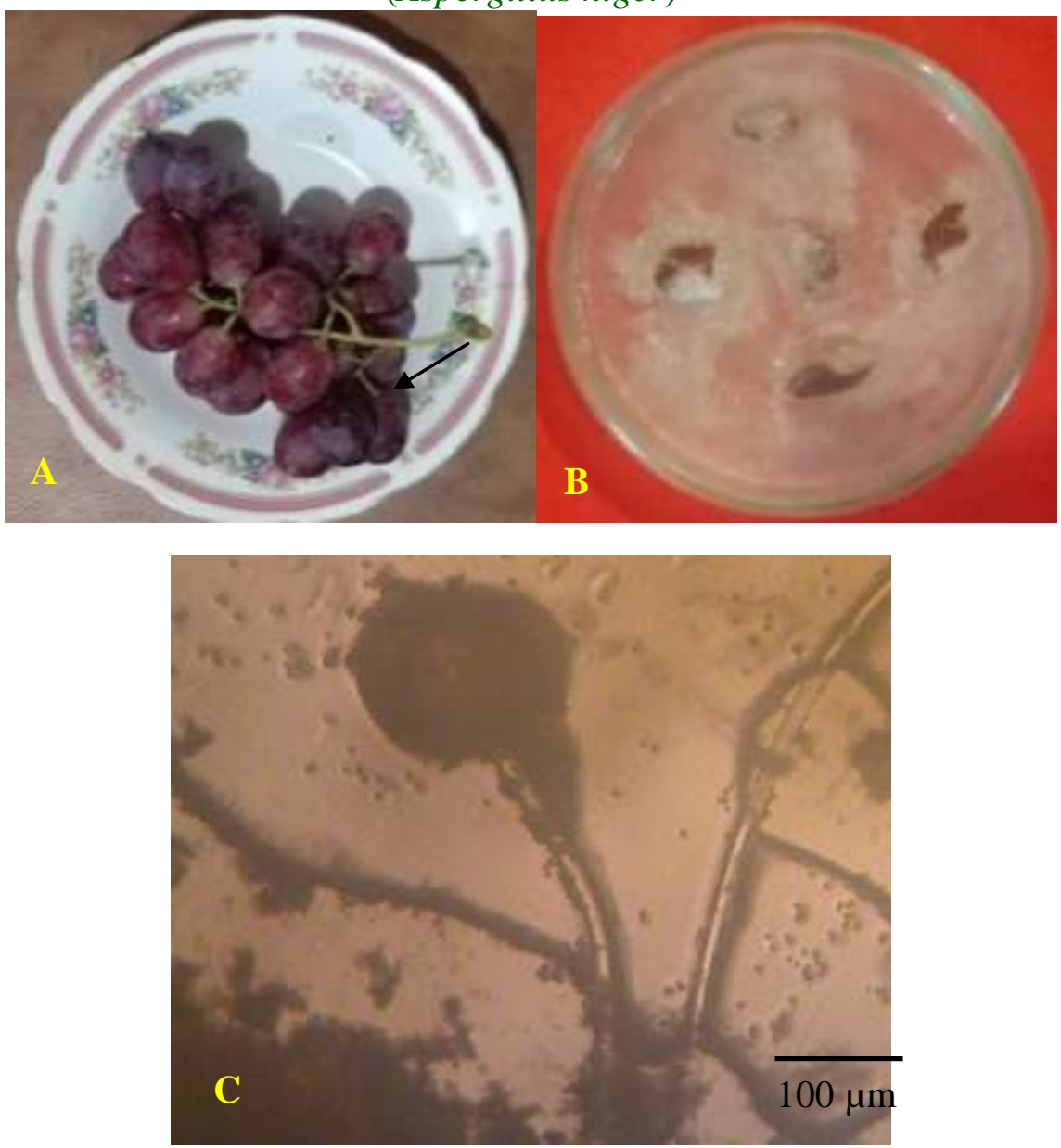

Fig.2 Number of fungal/Actinomycetes colonies found in red wine

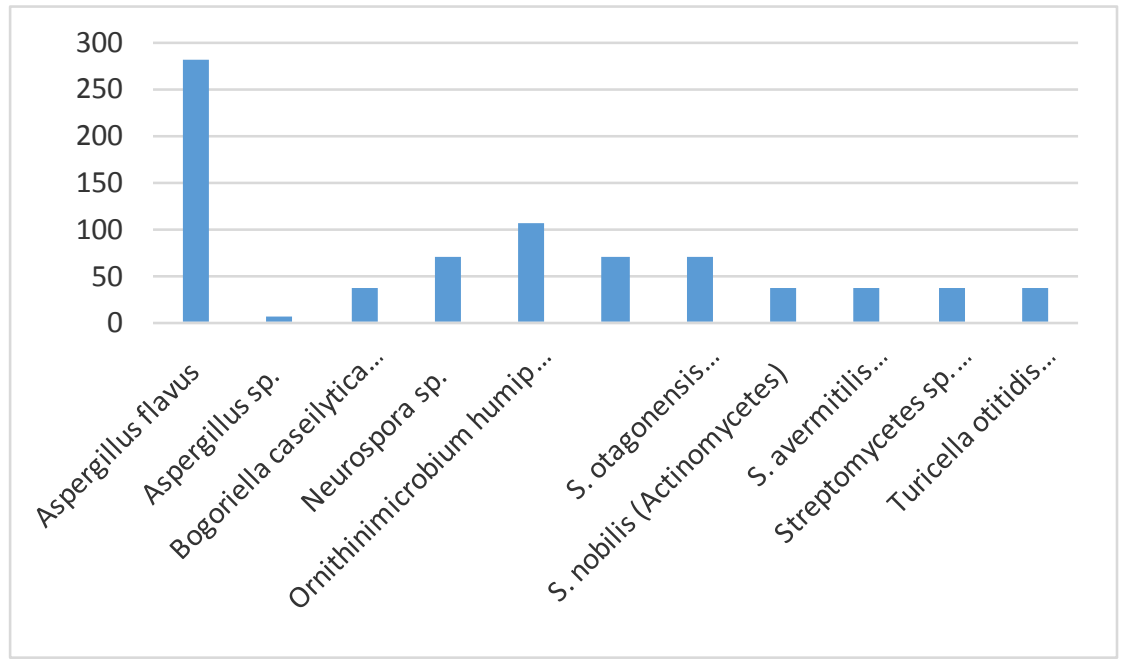


Fig.3 Effect of the best antagonistic treatment (Neurospora sp.) on the pathogenic rot of red grapes (Aspergillus niger) (Where: $\mathrm{A}=$ control (without being smeared with antagonists) + pathogens, $\mathrm{B}=$ antagonist treatment $(250 \mathrm{ml}$ aqua $(10 \%$ sugar mixture $)+$ spore suspension 1 Petri dish $)+$ pathogen, $\mathrm{C}=$ antagonist treatment $(500 \mathrm{ml}$ aqua $(10 \%$ sugar solution $)+$ spore suspension 1 Petri dish) + pathogen, $\mathrm{D}=$ antagonistic treatment $(750 \mathrm{ml}$ aqua $(10 \%$ sugar solution $)+$ spore suspension 1 Petri dish $)+$ pathogen, $\mathrm{E}=$ antagonist treatment $(1000 \mathrm{ml}$ aqua $(10 \%$ sugar solution $)+$ spore suspension 1 Petri dish $)+$ pathogen, $\mathrm{F}=$ antagonist treatment $(1250$ $\mathrm{ml}$ aqua (10\% sugar solution) + spore suspension 1 Petri dish), and $\mathrm{G}=$ without any treatment)
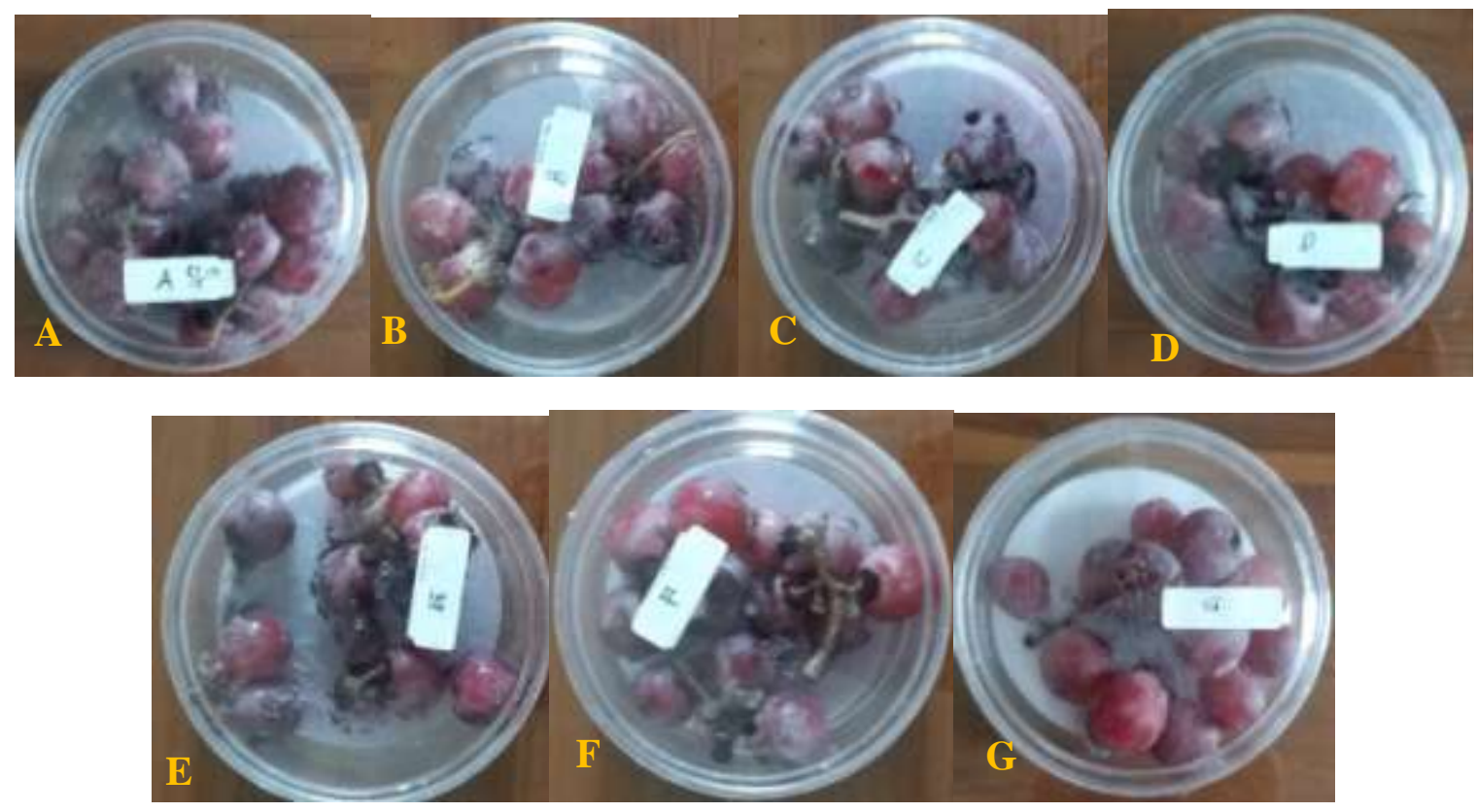

In vitro inhibitory test results on pathogens in red wine showed that exophytic and endophytic fungi that best inhibit pathogens are Neurospora sp. each at $88.89 \%$. In vivo test results of the best antagonistic fungal inhibition against pathogens have a very significant effect compared to controls. The best treatment was obtained from the treatment by adding an antagonistic spore suspension of $250 \mathrm{ml}$ of water, compared to other treatments.

\section{Acknowledgements}

Authors wish to thank to the Rector of Udayana University for their assistance and the opportunity given so that research can be resolved, Dean of the Faculty of Agriculture, Udayana University, and Chairman of the Institute for Research and Community Service Udayana University, for their help and cooperation so that research can be funded to completion.

\section{References}

Barnett, H.L. and B.B. Hunter. 1998. Illustrated Genera of Imperfect Fungi. APS Press. The American Phytopathological Sociey. St Paul, Minnesota.

Carroll, G.C. 1998. Fungal endophytes in stems and leaves: from latent pathogen to mutualistic symbiont. Ecol. 69:2-9.

Dutta, D., K.C. Puzari, R. Gogoi and P. Dutta. 2014. Endophytes: Exploitation as a Tool in Plant Protection. Brazilian Archives of Biology and Technology an International Journal 57(5): 621-629.

Ferianita-Fachrul, M., H. Haeruman, dan L.C. Sitepu. 2005. Komunitas Fitoplankton Sebagai Bio-Indikator Kualitas Perairan 
Teluk Jakarta. FMIPA-Universitas Indonesia Depok (Indonesian language).

Ghai, R. Tamura, Tomohiko, and Hamada. 2012. Atlas of Actinomycetes. Japan. Environ. Microbiol. Rep.4:29-35

Goswami, D. and M. Islam. 2002. In vitro study of antagonism of Trichodermaspp. andBacillus subtilis against Fusarium oxysporum f. sp. lycopersici(sacc). Journal of the Agriculturae Science. Soc.North- East India.15 (1): 5-12.

Indrawati. G., R.A. Samson, K. Van den TweelVermeulen, A. Oetari dan I. Santoso. 1999. Pengenalan Kapang Tropik Umum. Yayasan Obor Indonesia. Universitas Indonesia (University of Indonsia Culture Collection) Depok, Indonsia dan Centraalbureau voor Schirmmelcultures, Baarn, The Netherlands

Mojica-Marin, V., H. A. Luna-Olvera, C. Fco, Sandoval-Coronado, B. PereyraAlférez, H. Lilia, Morales-Ramos, E. Carlos, Hernández-Luna and G. O. Alvarado-Gomez. 2008. Antagonistic activity of selected strains of Bacillus thuringiensis against Rhizoctonia solani of chili pepper. African Journal of Biotechnology, 7 (9): 1271-1276.

Odum, E.P. 1971. Fundamentals of Ecology. Third Edition. W.B. Saunders Company.Philadelphia, Toronto, London. Toppan Company, Ltd. Tokyo, Japan.

Perello, A.E., Monaco, C.I., Moreno, M.V., Cordo, C.A. and Simon, M.R. 2006. The effectof Trichoderma harzianum and $T$. koningiion the control of tan spot (Pyrenophoratritici-repentis) and leaf blotch (Mycosphaerella graminicola) of wheat under fieldconditions in
Argentina. Biocontrol Sci and Technol. 16(8): $803-813$.

Pirzan, A.M., dan P. R. Pong-Masak. 2008. Hubungan Keragaman Fitoplanktondengan Kualitas Air di Pulau Bauluang, KabupatenT akalar, Sulawesi Selatan. Biodiversitas, 9 (3) 217-221.

Pitt, J.I. and A.D. Hocking. 1997. Fungi and Food Spoilage. Blackie Avademic and Professional. Second Edition. LondonWeinhein-New York-Tokyo-MelbouneMadras.

Rad, J.E., M. Manthey and A. Mataji. 2009. Comparison of plant species diversity with different plant communities in deciduous forests. Int. J. Environ. Sci. Tech., 6(3): 389-394.

Samson, R.A., E.S. Hoekstra, and C. A.N. Van Oorschot. 1981. Introduction to FoodBorne Fungi. Centraalbureau VoorSchimmel cultures. Institute of The Royal Netherlands. Academic of Arts and Sciences.

Sharma, R. 2012. Pathogenicity of Aspergillus niger in plants. Cibtech Journal of Microbiology 1(1): 2319-3867.

Strobel G.A, D.M. Long 1998) Endophytic microbes embody pharmaceutical potential. ASM News 64:263-268.

Yadav, S.L., A.K. Mishra, P.N. Dongre and R. Singh. 2011. Assessment of fungitoxicity of phylloplane fungi against Alternaria brassicae causing leaf spot of mustard. Journal of Agricultural Technology 7(6): 1823-1831.

Yang S.X, J.M, Gao, Q. Zhang, H.Laatsch. 2011. Toxic polyketides produced by Fusarium sp., an endophytic fungus isolated from Melia azedarach. Bioorg \& Med Chem Lett 21:1887-1889.

\section{How to cite this article:}

Made Sudarma, I., Ni Nengah Darmiati and Ni Wayan Suniti. 2019. Fungus and Actinomycetes Diversity of Exophytic and Endophytic in Red Grape and its Inhibition Ability to Pathogen Aspergillus niger (Caused Rot Fruit Grape). Int.J.Curr.Microbiol.App.Sci. 8(10): 2442-2451. doi: https://doi.org/10.20546/ijcmas.2019.810.284 